\title{
The Role of Institutions on Financial Inclusion in Indonesia
}

\author{
Syofriza Syofyan ${ }^{1}$, Bahtiar usman $^{2}$, Harmaini $^{3}$, Naptania Ilmas ${ }^{4}$ \\ \{syofriza.syofyan@trisakti.ac.id ${ }^{1}$, bachtiar.usman@trisakti.ac.id ${ }^{2}$, harmaini@trisakti.ac.id ${ }^{3}$, \\ naptaniailmas@gmail.com ${ }^{4}$ \} \\ Department of Economics, Faculty of Economics And Business, Trisakti University, \\ Indonesia ${ }^{1,2,3,4}$
}

\begin{abstract}
Increasing economic growth can be achieved by increasing financial deepening that involves financial inclusion. Household savings can be be a solution to finance development, if it can accumulate in large numbers and involve the whole society (inclusive). In institutional theory, it is revealed that banking system institutions can encourage / inhibit bank competition and are translated as transaction costs for the public in accessing financial institutions. This research aims to analyze the role of institutions on financial inclusion. Institutional role on financial inclusion was analyzed using OLS regression method in time series data, monthly from June 2004 to June 2019. The results of the study show that the institutional factor as measured the number of bank service offices is also a significant determining factor in influencing financial inclusion. Increasing financial inclusion can be achieved by increasing the affordability, (financial outreach) of people to formal financial institutions, both physically and non-physically (digital / virtual).
\end{abstract}

Keywords: Financial inclusion; institutional; financial outreach

\section{Introduction}

Financial inclusion can be interpreted as an effort to involve more economic actors to participate in the financial system. Financial inclusion can start with literacy and learning from both sides of the market, supply and demand. As part of financial development, financial inclusion is aimed at reducing several things, namely financial barriers, friction, asymmetric information, volatility, sensitivity of financing conditions to debtor assets, and strengthening the cycle through financial acceleration [1].

Mylenko and Park state that financial inclusion is a necessary condition for empowering the poor [2]. Empowerment is done by increasing the provision of financial services that make it easier for the poor to access them at a relatively lower cost and available in remote locations. An increase in savings ownership as a measure of increasing financial inclusion is considered a condition of positive financial behavior and leads to stability in family income. Savings can be used to smooth consumption throughout life, and make households able to 
face difficult times in life. Savings can also help households avoid drastic changes in consumption due to unemployment, disability or retirement from work. However, not all households have sufficient incentives to save, related to the ability to save [3]. Households that have low incomes or poor households, are unable to save and have no incentive to save.

Financial exclusion is a function of poverty [4]. Poor households, because they are excluded from the formal financial system and industry. They are unemployed, the people who can't work because of illness, the people who have low level of education and are located far from the city. They cannot access and obtain facilities and services in the formal financial system. The cycle and chain of poverty (vicious circle) can occur due to low and poor health and education services for poor children, both in terms of quality and availability. The high costs of transportation, school needs, and health services are economic factors that are difficult for the poor to overcome [5].

To achieve the main target of the Indonesian government in implementing sustainable development goals (SDGs), is to reduce poverty. As of 2019, 9.4\% of Indonesia's population still lives below the poverty line. The other three poverty indicators are the number of unemployed (4.7\%); the number of residents with a daily income of less than $\$ 1.90(4.3 \%)$; and the under-five mortality rate $(25 / 1000$ live births, 2018). In the context of alleviating the problem of poverty and breaking the cycle of poverty, the Indonesian government has taken various ways, one of which is to run several programs that increase the income of poor households in the form of social assistance in the form of PKH (Program Keluarga Harapan) since 2007, which in the way of distribution always experiences problems repair. The distribution of social assistance has become non-cash, conditional, sectoral, regional, and increasingly individualistic in terms of age, physical characteristics, or others. Empowerment and economic strengthening are also carried out for outstanding individuals and MSMEs in their infancy. The distribution of non-cash assistance is carried out directly from the government to the savings accounts of individual and/or beneficiary families.

The direct impact felt by the beneficiaries is an increase in saving capacity (ability, power to save). Therefore, the importance of distributing non-cash $\mathrm{PKH}$ is the main indicator for the successful adoption of technology and innovation in financial services according to the 2019 Inclusive Financial Acceleration Strategy at the Coordinating Ministry for Economic Affairs [6].

Poverty alleviation efforts can also be carried out by providing equal access to the financial sector, especially to the financially excluded (poor) community. Access to formal financial institutions and systems can be provided to people who are financially isolated by involving the participation of the local business community, either individual entrepreneurs and/or institutional entrepreneurs. The owner and/or manager of the stall is an individual entrepreneur. The business community is a requirement for membership of a Agen Laku Pandai (ALP). ALP is a branch office of a bank managed by selected individuals, institutions, and/or companies, namely the fulfillment of certain criteria and requirements. Although functioning as a branch office of a bank, ALP's operations and capacity are limited and microscale. Savings (basic saving account) is ALP's main product, starting from opening an account, accepting cash deposits, and cash withdrawal services, with no fees, no balance and minimum deposit. The second main function of ALP is as a payment point for the purposes of payment/purchase of utility products such as electricity, water, telephone, credit, and others. ALP can also receive tax and zakat payments.

Laku Pandai (branchless banking) is one of the government's policies to provide facilities to save for individuals who are financially isolated. The smart behavior policy acts as the spearhead and one of the breakthroughs in the banking industry to be able to enter 
uneconomical and unprofitable areas. High operational costs make banks have to be creative and innovative in order to have a far, wide, and affordable outreach (footprint). Affordability to formal financial institutions and systems is not limited to physical form, but also financially, which is the lowest (least cost) in terms of access fees and transaction costs. Promulgated by the OJK in June 2012, the smart behavior policy aims to bank the people, empowering certain people in the use of banking products, ranging from savings, loans, insurance, or other micro-scale financial products. These particular communities are people who are financially isolated due to various socioeconomic statuses, economic capabilities, and/or regional alienation. One of the functions of a bank is as an intermediary institution that facilitates financial transactions.

The government's policy in providing facilities to save for individuals who are financially isolated must also consider technological developments in payment transactions. Today, many transaction payments are completed without using cash (cashless). Transaction payments are made by transferring the balance from the buyer's account to the seller's account electronically. The account can be registered with a bank and/or electronic money service provider (Digital Financial Services or Layanan Keuangan Digital (LKD). At a bank, individual (and corporate) accounts can be in the form of regular savings, checking accounts, check accounts, or others. In LKD, the existing (individual) account is called a digital wallet (e-wallet).

The shift in transaction locations from physical to digital services is facilitated by the existence of low interest rates. LKD providers feel they have no obligation to pay interest on (electronic) money stored and managed by LKDs. On the other hand, LKD is obliged to provide ease of transactions, not to charge transaction fees, to provide protection to marketplace consumers through the establishment of an escrow account, acting as a custodian, and others.

Having a savings account is one indicator of the financial inclusion of an economy. In other words, the more financially inclusive an economy is, the less people will be financially excluded. Economic hardship is one of the causes of financial exclusion. Groups of people who are vulnerable to financial exclusion are people with low incomes, seniors, middle-aged people, toddlers, and people of compulsory school age.

One way to reduce poverty is to increase financial inclusion through household savings. Efforts to increase domestic savings by providing low-cost financial institutions with comprehensive services are in line with efforts to increase financial inclusion, because the level of financial inclusion in Indonesia is still relatively low and the inequality of savings account ownership for residents in Jakarta and outside Jakarta is still very high. Therefore, the inequality in the value of savings is also very high. The availability of low-cost financial institutions with comprehensive services is one solution to increase domestic savings [7].

On the other hand, to increase economic growth, it is necessary to increase financial deepening involving financial inclusion. Household savings can be a solution to finance development, if and only if it can be accumulated in large amounts and involves the whole community (inclusive). This study aims to analyze the role of institutional aspects on financial inclusion, with the research question: how is the role of institutions on financial inclusion in Indonesia.

\section{Literature Review}


The basic theory used in this study is the theory of savings, because savings ownership is one of the main measures of financial inclusion. In many concepts, theories, and empirical research, savings are often associated as a by-product of consumption theory, namely as residual income that is not consumed. On the other hand, in the view of the monetarists, saving is part of the demand for money to be spent based on needs and preferences that change according to time, place, event, and so on. The three common motives for asking (holding) money are for transactions, precautionary and speculative purposes. Baumol-Tobin's theory of demand for money is based on the principle of the lowest transaction cost (least cost).

In the view of neo-classical economists, delaying consumption is one of the rational saving preferences of individuals (households) in a perfectly competitive free market. One of the reasons for the delay in consumption could be due to insufficient funds needed at this time to buy something. Existing funds are saved (saved) to be spent when additional funds are available and sufficient. Another reason could be that there are other household needs that must be completed financially as soon as possible, require priority, cannot be postponed, or others

To date, the economic theory of saving has always been linked to and part of income and consumption. In the consumption function, saving is defined as what is not/has not been consumed from income, so all factors that affect consumption are also factors that affect saving. Theories related to this have been widely discussed such as neo-classical economic theory, namely the Keynes hypothesis, the permanent income hypothesis (PIH), the life cycle hypothesis (LCH), and the buffer stock hypothesis (BSH). The concept of PIH (permanent income hypothesis) was pioneered by Friedman [8]. While the concept of LCH (life cycle hypothesis) by Ando and Modigliani [9]. LCH was later developed by Deaton (1991) and Carroll into the concept of BSH (buffer-stock hypothesis) [10]-[12]. According to Deaton and Carroll's BSH concept is the foundation of the second generation consumption model. PIH and $\mathrm{LCH}$ are the first generation consumption models. As the development of the BSH concept being developed, MABS (multiple-asset buffer-stock) is the third generation consumption model.

On the other hand, in the view of the monetarists, saving is part of the demand for money to be spent based on needs and preferences that change according to time, place, event, and so on. The three common motives for asking (holding) money are for transactions, precautionary and speculative purposes. Baumol-Tobin's theory of demand for money is based on the principle of the lowest transaction cost (least cost). In the theory of demand for money by Baumol and Tobin, especially the motive for holding money for transaction purposes, it is said that the determinant of cash depends on several factors, including real income, real transaction value, interest rates and transaction intermediation costs [13], [14]. Transaction intermediation costs or transaction costs, in institutional theory are part of the social costs that should be borne by the parties that create negative externalities. Transaction costs can be measured by banking system institutions that encourage/inhibit bank competition. Transaction costs can be in the form of fees, interest, availability of formal financial institutions (easy access and technology).

\subsection{Relationship between Savings, Financial Deepening, and Financial Inclusion}

Theoretically, empowerment of the poor or the underprivileged can be done by providing financial access to formal financial institutions. Formal financial institutions are not always and must be conventional. This is based on the difficulty of achieving economies of scale amid the current high operating costs and overheads of financial institutions. Branchless 
banking (Officeless Financial Services in the Context of Financial Inclusion, Laku Pandai) then became one of the solutions.
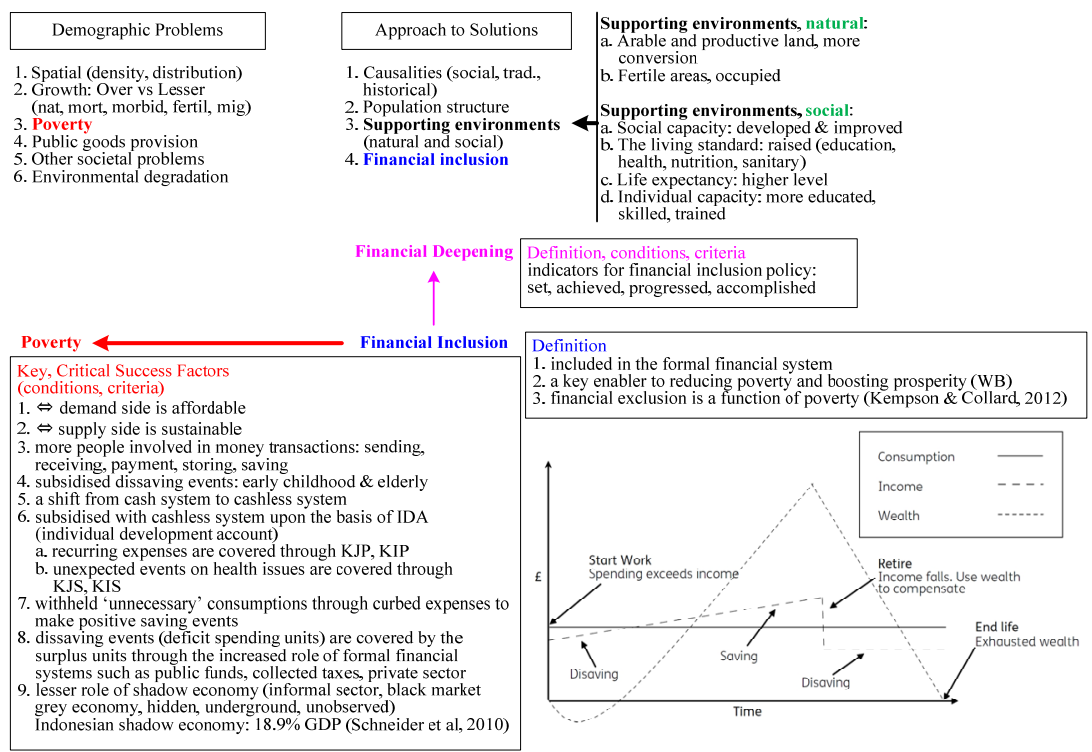

Fig. 1. Relationship between Savings, Financial Deepening, and Financial Inclusion Source: Syofyan (2018)

The purpose of financial deepening can be seen from 2 approaches, namely objective and/or subjective. The subjective approach is personal and personified, namely individuals and institutions. The objective approach can be explained through the variables inherent in economic actors such as efficiency, access, and availability (financial breadth and financial depth).

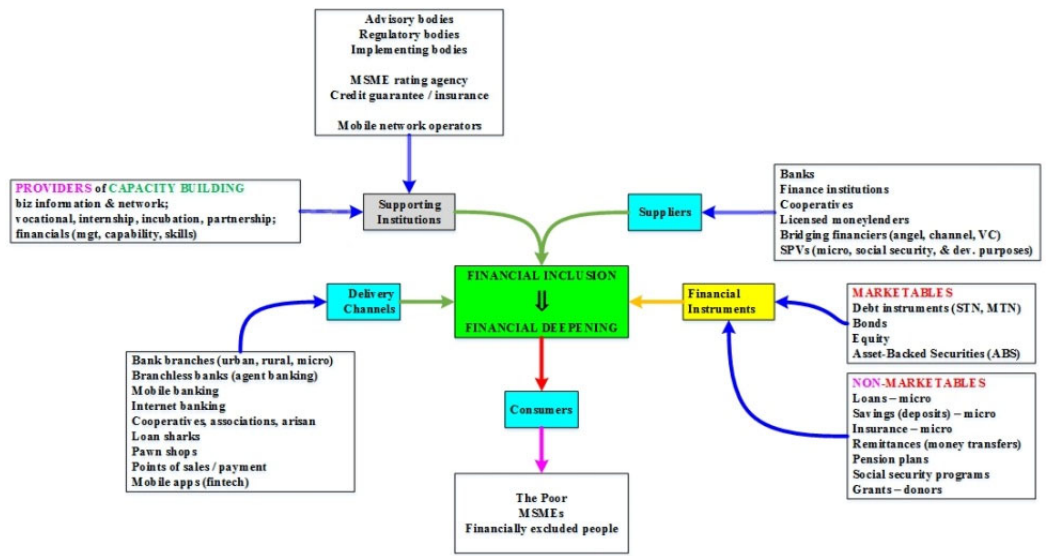

Fig. 2. Various elements of financial inclusion in the context of financial deepening Source: Modification of the Singh (2010) model. 
According to Singh, financial development is the impact of the interaction of various elements of the financial ecosystem on the implementation and policy of financial inclusion [15]. Various elements in financial inclusion include providers and users of financial services, financial instruments, supporting institutions, and delivery channels.

\subsection{Previous Research}

Research on the determinants of savings can be done from the side of savers and institutions, it can be seen from the side of the money saved which is associated with the demand side of money for transaction needs. Another approach is based on the availability of micro and macro level data. Several studies have classified the determinants of savings both macro and micro. In the macro data approach, Kirabaeva et al., classifies determinants of household savings into 6 groups of (macro) economic variables, namely income, demographics and social indicators, precautionary, fiscal, and financial [16]. Grigoli et al., mapped the determinants of private savings into 4 major groups, namely income, demographics, financial deepening, prices and fiscal policy [17]. In the microdata approach, several studies have discussed the role of individuals in saving based on the perspective of social and cultural background, socio-demographic characteristics, life experiences, cognitive capacity for financial affairs, and emotions related to money and savings Beverly and Sherraden; Sherraden and Barr; [18], [19]. These studies suggest that individual motives for saving are willingness to save, ability to save and facility to save. The motive is in the form of non-economic variables which can actually be measured by economic variables. One measurement that can be used is in the form of transaction costs. Transaction costs can be measured by banking system institutions that encourage/inhibit bank competition. Transaction costs in the form of fees, interest, availability of formal financial institutions (easy access and technology). Based on the theoretical description above, the following framework can be made:

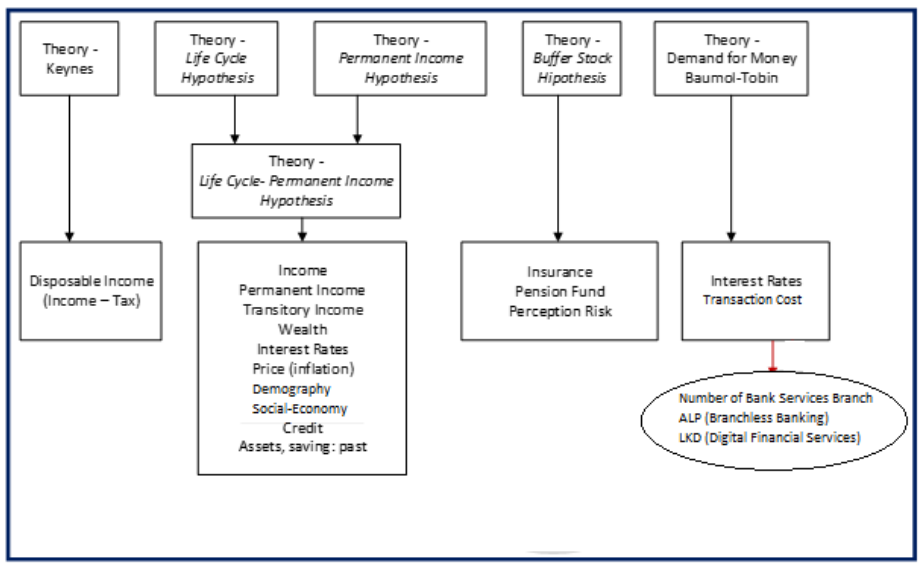

Fig. 3. Theoretical Framework

Based on the theoretical framework above, it can be hypothesized that institutional factors have a positive effect on increasing financial inclusion. When broken down into physical and technological institutional factors, the hypothesis can be written as follows: 
1. Availability of formal financial institutions will increase financial inclusion

2. Advances in technology (fintech) will increase financial inclusion

\section{Research Methodology}

This research is a quantitative research using secondary data. The data processing method used is time series data regression, by first conducting prerequisite tests on time series data, including stationarity tests, integration and cointegration degrees. This study uses macroeconomic data from Bank Indonesia (SEKI and SSKI), OJK, LPS, BPS, Lokadata, and the World Bank. The research period is June 2004 - June 2019 using quarterly data.

Financial inclusiveness can be seen with the increasing number of conveniences and choices for the public to access and obtain financial services anywhere and anytime. The public does not have to go to the physical location of a formal financial institution, except through digital financial service intermediaries (LKD) and/or Agen Laku Pandai (ALP).

Every observer and observer of financial inclusion has its own criteria in determining and measuring the development and implementation of financial inclusion policies in a region. Bank Indonesia, the Coordinating Ministry for Macroeconomics and Finance (KEMK), and the World Bank are three institutions that have and develop their own financial inclusion index. Presidential Decree No. 82/2016 also has its own criteria which state various parameters and indicators as well as the degree of measurement of financial inclusion.

The equation model for estimating the role of institutions towards financial inclusion uses the size of the 'provider' of financial services, namely the number of bank service offices and rural banks and ATMs; and related to fintech service 'providers', namely ALP, LKD, electronic money (issuers and merchants). Measurement of financial inclusion in the form of the number of account ownership and the value of public savings are grouped based on the value of savings.

\subsection{Inclusion Model I}

$\ln \operatorname{Sav}_{t}=\alpha+\beta_{1}$ Inc $_{t}+\beta_{2} \operatorname{Inf}_{t}+\beta_{3} I T_{t}+\beta_{4}$ Inst $_{t}+\beta_{5}$ Fintech $_{t}+\varepsilon_{t}$

The approach to this inclusion model I uses a model based on the research framework by including two macroeconomic variables, namely interest rates and inflation. Meanwhile, the number of rural banks (BPR), the number of ATMs, and the number of bank service offices (ln_bso) are integrated into financial inclusion variables; and the fintech variable (ln_fintech) is the natural $\log$ value of the number of Agen Laku Pandai (ALP), digital financial services (LKD), electronic money providers (UEI), and merchants receiving electronic money (UEM).

\subsection{Inclusion Model II}

Model II is an extension of model I with other macro variables, namely credit, PP (financing companies), pension funds, remittances and social assistance which are variables that have the potential to increase saving capacity, while for institutions it is broken down into the number of BPR, number of ATMs, and number of offices bank services (ln_bso), temporary and fintech are broken down into the natural log value of the number of Agen Laku Pandai (ALP), digital financial services (LKD), electronic money providers (UEI), and merchants receiving electronic money (UEM). 
In $\_$Sav $_{t}=\alpha+\beta_{1}$ Inc $_{t}+\beta_{2}$ Inf $_{t}+\beta_{3} I T_{t}+\beta_{4}$ Kred $_{t}+\beta_{5} P P_{t}+\beta_{6}$ Pens $_{t}+\beta_{7}$ remmit $_{t}+$ $\beta_{8}$ bansos $_{t}+\beta_{9}$ Inst $_{t}+\beta_{10}$ Fintech $_{t}+\varepsilon_{t}$

The financial inclusion regression equation model was created to determine the effect of 'easy access in conducting transactions in order to increase the degree of financial inclusion as measured by an increase in savings'. The size of the savings used is the number of savings accounts and the nominal value of the savings based on the class of savers that has been defined by the LPS. Where:

Sav : Number of accounts and savings value based on savings value classification group I with savings of up to Rp 100 million, group II (Rp 100 million - Rp 200 million), group III (Rp 200 million - Rp 1 billion), group IV (Rp 1 billion - Rp 2 billion); group V (Rp 2 billion - Rp 5 billion); and group VI (more than Rp 5 billion).

Inc $\quad:$ Disposibel Income = NNI (ln)

IT $\quad$ : Saving Interest (\%)

Inf : Inflation Rate (\%)

PP : assets of finance companies (ln)

Pens : assets of pension fund $(\ln )$

Remmit : remmitances of IMW (TKI) less remmitance of FMW (TKA) (ln rtki dan ln rtka)

Bansos : social protection services programs (ln)

Kred : bank credits (ln)

Inst : institutional factors (\# rural banks, bank service offices)

Fintech : fintech factors (\# of ATMs, digital financial services providers (LKD), agen laku pandai (ALP), electronic money (providers uei and merchants uem) (ln)

Et $\quad$ : error term representing variables excluded from the model with the assumption of IID (Independently Identical Distributed)

t : time period

\subsection{Data, Sources and Measurements}

Common sources of inclusive financial data come from BI (SEKI and SSKI), OJK, LPS, and BPS from Jun 2015-Jun 2019. In this study, the measure of financial inclusion is the number of savings accounts and the value of savings. The author defines small communities as owners of savings with small balances (small savers, small depositors). LPS makes a classification of savers based on 6 classes of nominal savings as defined above. The analytical tool used is the econometric method, time series data regression, and the software used is EViews 10.

\section{Result and Discussion}

\subsection{Savings}

The distribution of savings is uneven across Indonesia, holdings and the value of savings is concentrated in Jakarta. Nearly $90 \%$ of savings account owners are in Jakarta (August 2019), 
as well as the value of existing savings. In August 2019, 98\% of savings had a balance of less than $\mathrm{Rp} 100$ million, of which the owners of small rupiah savings accounts $(<\mathrm{Rp} 100$ million) amounted to 287 million accounts. During January 2013 to August 2019; the average share of rupiah savings accounts with a small balance is $98.04 \%$, which ranges from $97.67 \%$ to $98.33 \%$; and the monthly average growth in rupiah savings holdings was $1.16 \%$.

In the same month, August 2019, the total value of rupiah savings with large balances ( $>$ IDR $1 \mathrm{~m}$ ) amounted to IDR 2,917 trillion, or $58.38 \%$ of the total value of rupiah savings, or $50.29 \%$ of the total value of savings (rupiah and foreign currency). ). During January 2013 to August 2018, the average value of rupiah savings with large balances was $58.32 \%$; and ranged from $55.68 \%$ to $60.39 \%$. The value of rupiah savings with large balances experienced the largest average monthly growth $(0.84 \%)$ compared to other savings classes.

\subsection{Laku Pandai}

Based on the results of the branchless banking trial, OJK issued Regulation No.19/POJK.03/2014 concerning Laku Pandai (Officeless Financial Services in the Context of Financial Inclusion) as of November 18, 2014. Provisions for Laku Pandai by banks are regulated by OJK in SE No.6/SEOJK/2015. Laku Pandai was launched in June 2012 through the National Strategy for Financial Inclusion (SNKI). The aim is to bank the community, empowering certain people in the use of banking products, ranging from savings, loans, insurance, or other micro-scale financial products. These particular communities are people who are financially isolated due to various socioeconomic statuses, economic capabilities, and regional alienation.

As of March 2019, 1,073,134 Laku Pandai agents managed to raise 23,340,281 savings accounts with a value of IDR 2.51 trillion in 34 provinces and 510 districts/cities. Laku Pandai's participating banks consist of 26 conventional banks and 4 Islamic banks.

\subsection{LKD (Digital Financial Services)}

A few years before Laku Pandai started, Bank Indonesia had issued a policy related to financial inclusion called Digital Financial Services (LKD) as the provider, focusing on its product, e-money (electronic money). Several BI regulations related to e-money are as follows:

1. BI Regulation No.11/12/PBI/2009 concerning Electronic Money (Electronic Money)

2. BI Regulation No.16/8/PBI/2014 concerning Amendments to PBI No.11/12/PBI/2009

3. BI Regulation No.18/17/PBI/2016 concerning Amendment II to PBI No.11/12/PBI/2009

4. BI Regulation No.20/6/2018 concerning Electronic Money (EU)

As of August 2019, LKD registered with BI amounted to 432,289 units with LKD accounts totaling 56.14 million. From January 2015 to July 2019, LKD grew on average by $5.85 \%$ per month; with the number of accounts increasing by $12.18 \%$ per month. The drastic increase in account ownership began with the first occurring in October 2018 and the second in March 2019. In October 2018, the number of accounts increased by $172 \%$ to 9.71 million accounts; while in March 2019, the number of accounts increased 267\% to 43.68 million accounts.

EU stored on the card or on the server of the Issuer are called float funds. The maximum value for unregistered EU is IDR 2 million and IDR 10 million for registered EU. Especially for registered EU, the maximum value of incoming transactions is IDR 20 million per month. 
The EU movement must also be subject to and comply with the provisions of the transfer of funds that have been outlined in Law No. 3/2011 and PBI No. 14/23/PBI/2012; as well as various related regulations.

As of July 2019, the EU totaled 250.5 million; while the non-bank EU totaled 187.8 million. As of August 2019, there were 492 million EU transactions worth IDR 12.88 trillion. The EU's average monthly growth is $3.35 \%$ and the EU non-banks $4.55 \%$. Meanwhile, the average EU transaction frequency per month increased by $6.3 \%$ and the average transaction value grew by $7.61 \%$.

As of January 2019, electronic money (EU) which amounted to 189 million had exceeded the number of APMK (card payment instruments) which was at 181 million. The number of EU transactions is already approaching the APMK. As of August 2019, EU transactions totaled 492 million, while APMK transactions totaled 595 million. However, the transaction value of CBPIs is still much higher than the value of EU transactions, more than 50 times. As of August 2019, EU transactions were worth IDR 12.88 trillion, while APMK transactions were worth IDR 647.7 trillion. Together, the EU and APMK amounted to 443 million as of July 2019 with transactions totaling 1.12 billion worth IDR 717 trillion. Since January 2012, per month, the number of APMK and the EU has increased by $1.77 \%$; the number of transactions increased by $1.96 \%$; and transaction value grew by $1.42 \%$.

\subsection{ATM and Electronic Money as Cashless Tools}

Payment innovation can be done with process or product orientation. Process orientation includes payment initiation, the entire payment process (including clearing and settlement), payment receipts, and new schemes (such as e-money, virtual money, crypto currency). Product innovations include non-cash payments via the internet, card tapping, card swipe, SMS, electronic billing, contactless (NFC technology, Near Field Communications).

Cardless ATM has also become the latest fintech development, taking cash from ATMs without an ATM card. NFC is a technology used in cardless ATMs. The NFC contactless symbol is a trademark of EMVCo, LLC. The higher density of EDC (Electronic Data Capture) available in many PoS (Points of Sale) compared to ATM density is due to the lower cost of EDC operations when compared to operating ATMs in many places. However, ATMs are superior when compared to bank fees in operating branch offices. ATM transaction fees in traffic-heavy locations are $90 \%$ cheaper than operating branch offices.

Especially in Indonesia, when compared to conditions in 2011 , the number of ATMs in 2017 increased almost 2.5 times, from 41,836 units to 103,918 units, or an increase of $17.1 \%$ annually. However, the increase in the number of ATMs is decreasing every year. Meanwhile, per quarter, during the period from the end of 2015 to the end of 2017, the number of ATMs only increased by $1.05 \%$.

In 2012, the number of ATMs per 100,000 adults in Indonesia soared, i.e. more than doubled, from the level of 16.45 in 2011 to 35.78 in 2012. Since then, according to World Bank data, ATM accessibility in Indonesia is higher than all other countries in the world. In other words, through financial inclusion initiatives with ATM ownership as a measure, Indonesia's financial deepening is much better.

In their research on ATMs worldwide, Proverbio et al estimated that around 2 million ATMs were installed in 2010 and 3.2 million units in 2014, or an average increase of $12.4 \%$ per year. Meanwhile, the highest ATM penetration was in North America, which was at the level of more than 230 ATMs per 100,000 population in 2014. 
The average increase in ATM card issuance in Indonesia increased 6 times from the average increase in credit card issuance for the 2011-2017 period, and 65 times for the monthly period from the end of July 2017 to June 2018. For the 2011-2017 period, the number of cards credit increased by $2.6 \%$ annually, while ATM cards increased by $16.6 \%$. For the period July 2017 to June 2018, the number of credit cards increased by $6 \%$ o per month, while ATM cards increased by $41 \%$.

The impact is seen in the decrease in the share of credit card ownership which is compensated for by the increase in the share of ATM card ownership. The share of credit card ownership decreased from $80.3 \%$ in 2011 to $65.1 \%$ in June 2018. Meanwhile, the share of ATM cards increased from $19.6 \%$ to $34.9 \%$ for the same analysis period. In nominal terms, the number of credit cards was 4 times the number of ATM cards, namely in 2011, to decrease to 1.9 times in June 2018.

However, the number of credit cards and ATM cards when added up is still not proportional to the number of existing debit cards. In 2011, pure debit cards, excluding credit cards and ATMs, totaled 41.35 million. In May 2018, pure debit cards totaled 144.6 million, an increase of 3.5 times. In June 2018, the number of pure debit cards fell to 129.4 million, credit cards decreased slightly $(0.11 \%)$ to 17.25 million, and ATM cards increased $(1.1 \%)$ to 9.2 million.

\subsection{Regression results of equations 1 and 2}

Before processing the data, we conducted a stationarity test and a causality test to ensure that the data was feasible and that the dependent and independent variables were determined correctly. This is necessary because the relationship between variables is theoretically bidirectional like the relationship between savings and credit.

Granger Causality Test was conducted to see the direction of the relationship between groups of variables (determining savings, institutional and financial inclusion). Stationarity test was carried out on each variable using the unit root test principle. Causality Test for Financial Inclusion, Institutional and Savings Determinants). The result is that all variables are stationary at the 'first difference' and Granger causality test can be done with the selected lag using the smallest AIC (Akaike Info Criterion) criteria [20].

The results of the causality test, are that: in lag 1, the institutional variable group is proven to have more influence on the financial inclusion variable group and the determinants of savings, while the financial inclusion variable group influences each other with the savings determinant (reverse causality). Thus the test model for the estimation of the determinants of savings and the role of institutions in financial inclusion can be continued. In each of the displayed regression results, all OLS regression requirements have been met including the classical assumption violation test, $\mathrm{t}$ test and goodness of fit test.

\subsection{Equation I}

The actual and prominent first impression in the inclusion-I model is that income is not significant in determining savings. The value of savings with large balances (above IDR 2 billion) is positively influenced by 3 variables, namely inflation, institutional factors, and fintech variables.

Fintech variables can determine savings significantly, especially in the number of accounts and the value of savings with small balances (under IDR 200 million) and large balances. On the other hand, institutional variables (ln_inst) and interest rates have a negative impact on 
small savers, particularly on the number of accounts and the value of savings. Inflation also has a negative impact on small balance savings.

Table 1. Recapitulation of Equation I Result

\begin{tabular}{|c|c|c|c|c|}
\hline \multirow[t]{2}{*}{ Variabel } & $<200 \mathrm{~m}$, \#account & $>2 \mathrm{~b}$, \#account & $<200 \mathrm{~m}$, value & $>2 \mathrm{~b}$, value \\
\hline & ln_sav_r12 & In_sav_r67 & In_sav_n12 & In_sav_n67 \\
\hline \multirow[t]{2}{*}{ ln_inc } & -0.0787 & -0.0727 & -0.00764 & 0.0813 \\
\hline & $(0.158)$ & $(0.0995)$ & $(0.111)$ & $(0.117)$ \\
\hline \multirow[t]{2}{*}{ Inf } & 0.000378 & 0.000316 & $-0.0114 * * *$ & $0.0206^{* * *}$ \\
\hline & $(0.00523)$ & $(0.00329)$ & $(0.00367)$ & $(0.00387)$ \\
\hline \multirow[t]{2}{*}{ interest } & $-0.319 * * *$ & -0.0453 & $-0.256^{* * *}$ & -0.0999 \\
\hline & $(0.0863)$ & $(0.0543)$ & $(0.0605)$ & $(0.0638)$ \\
\hline \multirow[t]{2}{*}{ ln_inst } & $-1.429 * * *$ & 0.424 & $-1.049 * * *$ & $1.532 * * *$ \\
\hline & $(0.404)$ & $(0.254)$ & $(0.283)$ & $(0.298)$ \\
\hline \multirow[t]{2}{*}{ ln_fintech } & $0.359 * * *$ & $0.161 * * *$ & $0.134 * * *$ & $0.158 * * *$ \\
\hline & $(0.0510)$ & $(0.0320)$ & $(0.0357)$ & $(0.0377)$ \\
\hline \multirow[t]{2}{*}{ _cons } & $31.28 * * *$ & $6.610 *$ & $23.80 * * *$ & -5.311 \\
\hline & $(5.555)$ & $(3.491)$ & $(3.893)$ & $(4.105)$ \\
\hline $\mathrm{N}$ & 45 & 45 & 45 & 45 \\
\hline Prob F-stat & 0.000 & 0.000 & 0.000 & 0.000 \\
\hline Adj R2 & 0.9816 & 0.9625 & 0.9701 & 0.9722 \\
\hline
\end{tabular}

\subsection{Equation II}

In model 2, income is still not significant in determining savings, the effect of negative inflation on large saver account ownership (above Rp 2 billion), and conversely interest rates have a positive effect on large saver account ownership, but interest rates have a negative effect on the value of large savers' savings.

The addition of other variables that reflect the capacity to save, such as PP (financing companies, pension funds, remittances and social assistance, only has a significant effect on the value of large savers' savings, where financing company credit has a positive effect, remittance has a negative effect. Meanwhile, the credit variable significantly affects savers' account ownership. large and the value of the savings of small savers.

Based on the institutional variables broken down into the number of BPRs, the number of ATMs and the number of bank service offices (ln_bso) it shows that the number of bank service offices has proven to be significant in increasing the number of savings accounts for both small savers and large savers and besides that it also increases the value of small savers' savings. Meanwhile, the fintech variable that breaks down into the natural log value of the number of smart behavior agents (ALP), digital financial services (LKD), electronic money providers (UEI), and electronic money recipient merchants (UEM), shows the results that the number of electronic money providers ( ln_uei) has a positive effect on the increase in the number of small saving accounts.

Table 2. Recapitulation of Equation II Result

\begin{tabular}{|c|c|c|c|c|}
\hline \multirow{2}{*}{ Variabel } & $<200 \mathrm{~m}$, \#account & $>2 \mathrm{~b}$, \#account & $<200 \mathrm{~m}$, val & $>2 \mathrm{~b}$, val \\
\hline & In_sav_r12 & In_sav_r67 & In_sav_n12 & In_sav_n67 \\
\hline \multirow[t]{2}{*}{ ln_inc } & -0.153 & -0.142 & -0.187 & -0.0983 \\
\hline & -0.185 & -0.101 & -0.136 & -0.136 \\
\hline \multirow[t]{2}{*}{ Inf } & -0.00485 & $-0.00926^{*}$ & -0.00645 & 0.0106 \\
\hline & -0.00971 & -0.00531 & -0.0071 & -0.00711 \\
\hline
\end{tabular}




\begin{tabular}{|c|c|c|c|c|}
\hline \multirow{2}{*}{ Variabel } & $<200 \mathrm{~m}$, \#account & $>2 \mathrm{~b}$, \#account & $<200 \mathrm{~m}$, val & $>2 \mathrm{~b}, \mathrm{val}$ \\
\hline & In sav r12 & In sav r67 & In sav n12 & In sav n67 \\
\hline \multirow[t]{2}{*}{ interest } & -0.12 & $0.224 * * *$ & 0.0691 & $-0.252 * * *$ \\
\hline & -0.117 & -0.0637 & -0.0853 & -0.0854 \\
\hline \multirow[t]{2}{*}{ ln_kredit } & -0.092 & $0.648 * *$ & $0.894 * *$ & -0.48 \\
\hline & -0.525 & -0.287 & -0.384 & -0.384 \\
\hline \multirow[t]{2}{*}{ ln_pp } & 0.562 & 0.512 & 0.376 & $0.791 *$ \\
\hline & -0.589 & -0.322 & -0.431 & -0.431 \\
\hline \multirow[t]{2}{*}{ ln_pensiun } & 0.0657 & 0.18 & -0.0877 & 0.104 \\
\hline & -0.203 & -0.111 & -0.148 & -0.148 \\
\hline \multirow[t]{2}{*}{ ln_rtki } & 0.126 & -0.0921 & 0.0631 & $-0.141^{*}$ \\
\hline & -0.111 & -0.0605 & -0.0809 & -0.081 \\
\hline \multirow[t]{2}{*}{ ln_rtka } & 0.025 & -0.02 & 0.0268 & $-0.254 * * *$ \\
\hline & -0.0925 & -0.0506 & -0.0677 & -0.0678 \\
\hline \multirow[t]{2}{*}{ ln_bansos } & 0.00491 & -0.00292 & -0.000872 & 0.00566 \\
\hline & -0.00981 & -0.00536 & -0.00718 & -0.00719 \\
\hline \multirow[t]{2}{*}{ ln_bpr } & 0.00882 & -0.119 & 0.0676 & 0.131 \\
\hline & -0.171 & -0.0935 & -0.125 & -0.125 \\
\hline \multirow[t]{2}{*}{ ln_bso } & $1.511^{*}$ & $1.577 * * *$ & $1.158^{*}$ & 0.96 \\
\hline & -0.808 & -0.442 & -0.591 & -0.592 \\
\hline \multirow[t]{2}{*}{ ln_atm } & 0.718 & 0.00956 & 0.0373 & -0.321 \\
\hline & -0.653 & -0.357 & -0.478 & -0.478 \\
\hline \multirow[t]{2}{*}{ ln_lkd } & 0.00184 & 0.0349 & 0.0207 & 0.0464 \\
\hline & -0.0631 & -0.0345 & -0.0461 & -0.0462 \\
\hline \multirow[t]{2}{*}{ ln_alp } & -0.00873 & -0.0133 & -0.0117 & 0.0071 \\
\hline & -0.0146 & -0.008 & -0.0107 & -0.0107 \\
\hline \multirow[t]{2}{*}{ ln_uei } & $0.350 * *$ & 0.0154 & -0.0515 & 0.0614 \\
\hline & -0.129 & -0.0706 & -0.0945 & -0.0946 \\
\hline \multirow[t]{2}{*}{ ln_uem } & 0.00184 & 0.0349 & 0.0207 & 0.0464 \\
\hline & -0.0631 & -0.0345 & -0.0461 & -0.0462 \\
\hline \multirow[t]{2}{*}{ _cons } & $0.161 * *$ & 0.0295 & 0.0439 & $0.145^{* *}$ \\
\hline & -0.0752 & -0.0411 & -0.055 & -0.0551 \\
\hline $\mathrm{N}$ & 45 & 45 & 45 & 45 \\
\hline Prob F-stat & 0.000 & 0.000 & 0.000 & 0.000 \\
\hline Adj R2 & 0.9903 & 0.9851 & 0.9829 & 0.9857 \\
\hline SW Prob & 0.05256 & 0.51732 & 0.35522 & 0.32541 \\
\hline BP Prob & 0.1034 & 0.2043 & 0.3802 & 0.2187 \\
\hline DW stat & 1.39165 & 2.243478 & 1.787595 & 2.217046 \\
\hline
\end{tabular}

\subsection{Discussion of Regression Results}

The estimation model is built on 2 simple sentences, but has a strong meaning, namely: Financial exclusion is a function of poverty [4]. Financial inclusion starts with payments. These two sentences are very meaningful and imply many things. Payments from regular recurring orders begin with utilities to pay monthly bills such as telephone, water, electricity, tv, and the like directly to the provider's office.

The application of an open system bank allows monthly bills to be paid and settled with the bank account of each utility provider. Third parties are starting to step in with lower fees than banks charge to deliver payment services. Once trust is successfully built and maintained, the payment outlet must maintain sufficient funds with the third party to keep it operating as usual. In due course, the third party is then allowed to deposit the individual's deposit as an 
end user on a card (with magnetic stripe and/or embedded chip) or electronic wallet to complete any financial transactions, offline and online.

These savings collected by third parties function as units of surplus spending. The temptation to finance deficit spending is enormous. Their target is financing for individuals and MSMEs (micro and small and medium enterprises) with a small loan nominal but for a large number of clients (breadth). This niche market has been abandoned by banks. To maintain their liquidity, these third parties can raise funds with lots of money in circulation. As a result, more financial products can serve and are available in the market.

As more individuals engage and rely on third parties to offer financial services, the degree of financial inclusion of a country becomes higher. Therefore, by analogy with Kempson and Collard's statement above, the poverty rate of a country is decreasing. Unfortunately, this study does not look for the effect of financial inclusion on a country's poverty, but looks for the role of institutions in financial inclusion. This study aims to find out the role of institutions that can significantly determine savings and financial inclusion, either positive, negative, both, or neither.

To some extent, financial inclusion is the result of a country's efforts in financial deepening and financial development. However, to get there, commoners and common people need to be educated financially to reduce financial illiteracy and improve financial literacy in general. The estimation model in this study categorizes the determinant variables into 4, namely income/financial factors, macro variables, and institutions (both physically and technologically). The technological side of the institutional role is that it is separated into its own sub-class, namely fintech.

In model 1 , of the 5 independent variables that are estimated to be able to determine savings, the institutional variable (institutional) can actually predict significantly, especially the number of accounts and the value of savings with a balance of less than Rp 200 million and the value of savings with a balance of more than Rp 2 billion, but not significant in terms of determining the number of accounts with a balance of more than $\mathrm{Rp} 2$ billion.

In model 2, when LKBB (Non Bank Financial Institurions) elements are included, namely assets of finance companies and pension funds, the bank service office loses its significance to the value of large accounts. However, the bank service office remains significant in terms of determining the number of large accounts, namely at $=1 \%$. The number of electronic money providers (ln_uei) has a positive effect on increasing the number of small saving accounts

The existence of financial institutions, both physically (such as the number of bank service offices), and technologically (such as the number of electronic money providers) has a positive effect on savings ownership. The ability of financial institutions to be present and exist physically and virtually / technology, can be interpreted that they do and are proven to improve facilities for saving overall.

Local or nearby financial institutions are considered important in determining savings holdings, unfortunately, the role of rural banks appears to be understating the value of savings. This is possible because the role of BPR in collecting customer savings is small compared to conventional banks. Likewise the role (number) of ALP, and LKD. On the other hand, electronic money issuers and merchants seem to be important in determining savings. In this study, the number of bank service offices is consistent in determining the ownership of savings and the value of savings in a positive manner. This means that the number of bank service offices does provide facilities for saving

\section{Conclusions and Suggestions}


The regression results show that institutional factors are consistently significant variables in influencing financial inclusion (as measured by savings ownership and savings value). The availability of a bank branch office or formal financial institution is primarily one of the significant factors affecting savings ownership and the value of savings. This indicates that people need good institutions to be able to save, related to the number of institutions and transaction costs, as stated by Freytag and Voll [7].

The interest rate factor has no significant effect on savings ownership and the value of savings and even has a negative effect on 'small balance savers' savings. This is possible because interest rates are not someone's motive to create a savings account and increase the amount of savings, because the savings interest rate is relatively small, especially for savers with small balances. Someone creates a savings account for the purpose of 'easy' transactions. When someone already has an account/account at a bank, it will facilitate the process of sending/receiving money, getting social assistance facilities, facilitating online transactions and other conveniences.

Institutional factors, both physical and technological, have been shown to be significant in influencing savings ownership and value. Massive adoption of newly developed technologies in every day of life, practiced by all classes of society, without boundaries, and without physical 'limitations' of space and distance. The much greater convenience offered by fintech companies, supported by the banking industry and existing payment systems, is not without risks and consequences. Breakthroughs in fast financial transactions along with enacting functions such as custodial and settlement pose serious challenges in terms of security, customer data breaches, embezzlement and fraud. This needs to be a major concern for OJK as a fintech supervisory agency to always update and be aware of fintech developing in Indonesia, especially during the COVID-19 pandemic.

It should be noted that people tend and will use financial facilities that provide convenience and low cost. The ease of opening savings accounts and loans at banks or fintech companies becomes meaningless if there is no money circulation. When people do not have the sources of funds to use these financial facilities, the goal of facilitating financial technology to increase financial inclusion is not achieved, therefore the government needs to think of ways to increase people's saving capacity such as providing credit facilities, especially for small entrepreneurs and MSMEs. In addition, the government also needs to improve the mechanism for providing assistance/subsidy to the community so that it has an impact on increasing saving capacity. The provision of assistance without completion and specific criteria is often not right on target and is counter-productive [21].

Regarding to the proposed government policy draft to increase household savings, it is necessary to have a formal financial institution for saving that is facilitated by the government and available in all corners of the country, so that most households who do not have a bank account can easily get one. The existence of BRI, BPR so far have been able to quickly adopt technological advances, it is expected to be able to increase financial inclusion.

\section{References}

[1] B. Bernanke, M. Gertler, dan S. Gilchrist, "The Financial Accelerator in a Quantitative Business Cycle Framework," Massachusetts, 6455, 1999.

[2] N. Mylenko dan D. Park, "Financial Inclusion in Developing Asia: Transactional Accounts, Savings, and Borrowing," ABF157572, 2015.

[3] S. J. Heckman dan S. D. Hanna, "Individual and Institutional Factors Related to Low- 
Income Household Saving Behavior," J. Financ. Couns. Plan., vol. 26, no. 2, hlm. 187-199, 2015.

[4] E. Kempson dan S. Collard, Developing a vision for financial inclusion. Bristol: University of Bristol for Friends Provident Foundation, 2012.

[5] World Bank, Little Data Book on Financial Inclusion. Washington DC: World Bank, 2015.

[6] I. Simorangkir, "Laporan Kinerja Tahun 2018," Jakarta, 2019.

[7] A. Freytag dan S. Voll, "Institutions and Savings in Developing and Emerging Economies," Public Choice, vol. 157, hlm. 475-509, 2013.

[8] M. Friedman, A Theory of the Consumption Function. Princeton: Princeton University Press, 1957.

[9] A. Ando dan F. Modigliani, "The Life Cycle Hypothesis of Saving: Aggregate Implications and Tests," Am. Econ. Rev., vol. 53, no. 1, hlm. 55-84, 1963.

[10] A. Deaton, "Saving and Liquidity Constraints," Econometrica, vol. 59, no. 5, hlm. 1221-1248, 1991.

[11] C. D. Carroll, "The Buffer-Stock Theory of Saving: Some Macroeconomic Evidence," Brookings Pap. Econ. Act., vol. 2, hlm. 61-156, 1992.

[12] C. D. Carroll, "Buffer-Stock Saving and the Life Cycle/Permanent Income Hypothesis," Q. J. Econ., vol. 112, no. 1, hlm. 1-55, 1997.

[13] W. Baumol, "The Transactions Demand for Cash: An Inventory Theoretic Approach," Q. J. Econ., vol. 66, hlm. 545-556, 1952.

[14] J. Tobin, "The Interest Elasticity of the Transactions Demand for Cash," Rev. Econ. Stat., hlm. 241-247, 1956.

[15] M. Naghavi $d k k$., "Global, regional, and national age-sex specific all-cause and causespecific mortality for 240 causes of death, 1990-2013: A systematic analysis for the Global Burden of Disease Study 2013," Lancet, vol. 385, no. 9963, hlm. 117-171, 2015, doi: 10.1016/S0140-6736(14)61682-2.

[16] K. Kirabaeva, A. O. Santos, Y. Cai, dan V. Crispolti, "Household Saving in Portugal," 19/222, 2019.

[17] F. Grigoli, A. Herman, dan K. Schmidt-Hebbel, "World Saving," WP/14/204, 2014.

[18] S. G. Beverly dan M. Sherraden, "Institutional Determinants of Saving: Implications for Low-Income Households and Public Policy," J. Behav. Exp. Econ., vol. 28, no. 4, hlm. 457-473, 1999.

[19] M. Sherraden dan M. S. Barr, "Institutions and Inclusion in Saving Policy," in Building Assets, Building Wealth: Creating Wealth In Low-Income Communities, N. Retsinas dan E. Belsky, Ed. Washington DC: Brookings Press, 2005.

[20] D. N. Gujarati, Basic Econometrics. New Delhi: McGraw-Hill Education, 2009.

[21] S. Syofyan, "Penentu Tabungan dan Peranan Kelembagaan dalam Inklusi Keuangan," Universitas Indonesia, 2021. 